\title{
Reviewer Acknowledgements for Global Journal of Health Science, Vol. 11, No. 5
}

Global Journal of Health Science wishes to acknowledge the following individuals for their assistance with peer review of manuscripts for this issue. Their help and contributions in maintaining the quality of the journal are greatly appreciated.

Global Journal of Health Science is recruiting reviewers for the journal. If you are interested in becoming a reviewer, we welcome you to join us. Please find the application form and details at http://recruitment.ccsenet.org and e-mail the completed application form to gjhs@ccsenet.org.

\section{Reviewers for Volume 11, Number 5}

Ama Pokuaa Fenny, University of Ghana, Ghana

António Calha, Polytechnic Institute of Portalegre, Portugal

Ayesha Johnson, University of South Florida, United States of America

Caroline Home, University of Technology Sydney, Australia

Darampal Dambhare, Mahatma Gandhi Institute of Medical Sciences, India

David Otieno Odongo, Masinde Muliro University of Science and Technology, Kenya

David Richard Walwyn, University of Pretoria, South Africa

Emad Adel Shdaifat, Imam Abdulrahman Bin Faisal University, Saudi Arabia

Faik Ardahan, Akdeniz University, Turkey

Farahnaz Amini, UCSI University, Malaysia

Jason Tsai, Lincoln College, United Kingdom

José Joaquín Mira, Universidad Miguel Hernández, Spain

Lisa Scherer, University of Nebraska at Omaha, USA

Marcel Wullschleger, University of Bern, Switzerland

Meng Zhao, Texas A\&M University at Corpus Christi, United States of America

Misheck Dube, North West University, South Africa

Pi-Ming Yeh, Missouri Western State University, United States

Polly Yeung, Massey University, New Zealand

Sara Melo, Queen's University Belfast, United Kingdom

Tan Ching Siang, Universiti Sciences Malaysia, Malaysia

Thammanard Charernboon, Thammasat University, Thailand

Thanusin Saleeon, Ministry of Public Health, Thailand 